\title{
Insekticidni proteini in njihova uporaba za zatiranje koloradskega hrošča (Leptinotarsa decemlineata [Say, 1824])
}

\author{
Primož ŽIGON ${ }^{1,2}$, Jaka RAZINGER ${ }^{1}$, Stanislav TRDAN ${ }^{3}$
}

Received May 27, 2021; accepted August 24, 2021. Delo je prispelo 27. maja 2021, sprejeto 24. avgusta 2021

Insecticidal proteins and their potential use for Colorado potato beetle (Leptinotarsa decemlineata [Say, 1824]) control

Abstract: Plants respond to pest attack, among other mechanisms, by producing specific proteins with insecticidal properties. Proteins with toxic effects on insects have also been discovered in many other organisms, especially fungi and bacteria. Due to their biological function, insecticidal proteins represent an important potential in the development of more environmentally friendly plant protection methods. Increasing knowledge about the mode of action of insecticidal proteins and the identification of genes encoding their synthesis enable the breeding of transgenic plants resistant to insect pests and the development of new bioinsecticidal agents. The Colorado potato beetle (Leptinotarsa decemlineata) is one of the most important pests of potato, so the study of such control methods is crucial for the development of sustainable integrated pest management strategies of potato. This review highlights the properties of some groups of insecticidal proteins and their modes of action, and summarizes examples of studies of their use for the control of Colorado potato beetle.

Key words: entomotoxic proteins; bioinsecticide; plant toxins; potato; insecticide resistance
Insekticidni proteini in njihova uporaba za zatiranje koloradskega hrošča (Leptinotarsa decemlineata [Say, 1824])

Izvleček: Rastline se na napad škodljivcev odzovejo med drugim tudi $s$ tvorbo specifičnih proteinov $\mathrm{z}$ insekticidnim delovanjem. Proteine s toksičnim delovanjem na žuželke so odkrili tudi v številnih drugih organizmih, predvsem glivah in bakterijah. Zaradi omenjene biološke funkcije insekticidni proteini predstavljajo pomemben potencial v razvoju okolju prijaznih metod varstva rastlin. Poznavanje mehanizmov delovanja insekticidnih proteinov in identifikacija genov za njihovo sintezo omogočata žlahtnjenje transgenih sort rastlin odpornih na škodljive žuželke ter razvoj bioinsekticidnih učinkovin. Koloradski hrošč je pomemben škodljivec krompirja, zato je preučevanje tovrstnih načinov varstva rastlin ključno za razvoj trajnostnih strategij integriranega varstva krompirja. V prispevku povzemamo lastnosti nekaterih skupin insekticidno delujočih proteinov in njihovih mehanizmov delovanja ter primerov preučevanja njihove uporabe za zatiranje koloradskega hrošča.

Ključne besede: entomotoksični proteini; bioinsekticidi; rastlinski toksini; odpornost; krompir

1 Kmetijski inštitut Slovenije, Oddelek za varstvo rastlin, Hacquetova 17, SI-1000 Ljubljana

2 Korespondenčni avtor, e-naslov: primoz.zigon@kis.si

3 Univerza v Ljubljani, Biotehniška fakulteta, Oddelek za agronomijo, Jamnikarjeva 101, SI-1000 Ljubljana 


\section{UVOD}

Rastline so med evolucijo razvile različne mehanizme za obrambo pred rastlinojedimi organizmi. Odziv rastlin na mehanske poškodbe zaradi napada grizočih žuželk vključuje morfološke prilagoditve in sintezo različnih kemičnih snovi, od preprostejših spojin do kompleksnejših proteinskih struktur, ki zavirajo rast, razvoj ter razmnoževanje škodljivih organizmov (Tripathi in Mishra, 2016). Pomemben del induciranega obrambnega odziva rastlin na napad škodljivcev je tvorba insekticidno delujočih proteinov. Najbolj znani proteini s tovrstnim odzivom na škodljivce so lektini in inhibitorji različnih prebavnih encimov, kot so $\alpha$-amilaze in proteaze ter nekateri drugi (Dang in Van Damme, 2015).

Insekticidne proteine poleg rastlin proizvajajo tudi številni drugi organizmi. Do danes so bili identificirani različni proteini rastlinskega, živalskega in mikrobiološkega izvora $s$ toksičnim delovanjem na vrsto žuželk. Sodobne biotehnološke metode so v zadnjih desetletjih omogočile velik napredek tudi pri identifikaciji genov, odgovornih za sintezo omenjenih snovi in transformacijo rastlinskih tkiv za namene povečanja odpornosti proti rastlinskim škodljivcem (Carlini in Grossi-De-Sá, 2002; Tripathi in Mishra, 2016).

V kmetijstvu se za omejevanje izpada pridelka zaradi škodljivih organizmov tradicionalno poslužujemo uporabe kemičnih insekticidov, kar pa zaradi številnih negativnih okoljskih učinkov in naraščajoče problematike odpornosti proti aktivnim snovem povečuje potrebo po iskanju alternativnih pristopov varstva rastlin (Trdan, 2013, 2016). Uporaba transgenih rastlin predstavlja pomemben potencial za zmanjševanje odvisnosti kmetijske pridelave od uporabe sintetičnih insekticidov (Tripathi in Mishra, 2016).

$\mathrm{V}$ tem smislu imajo vse večji pomen kot metoda nekemičnega varstva rastlin tudi biopesticidi. Biopesticidi so snovi na podlagi mikroorganizmov ali naravnih produktov in $\mathrm{v}$ tem smislu predstavljajo okoljsko sprejemljivejši način zatiranja škodljivih organizmov. Po nekaterih definicijah se med biopesticide uvrščajo tudi snovi, ki jih tvorijo rastline $\mathrm{z}$ dodanim genetskim materialom $\mathrm{z}$ uporabo metod genskega inženiringa (Plant-Incorporated-Protectants ali PIPs) (United States Environmental Protection Agency, 2017). Uporaba insekticidnih proteinov bakterijskega izvora predstavlja enega pomembnejših mehanizmov delovanja biopesticidov (Paul in Das, 2020).

Insekticidni proteini se razlikujejo glede na izvor in način delovanja na ciljne organizme. Koloradski hrošč je najpomembnejši škodljivec krompirja, problematika njegovega zatiranja pa je zaradi pojava odpornih po- pulacij proti večini kemičnih insekticidov in splošne okoljske problematike rabe kemičnih sredstev za varstvo rastlin predmet številnih raziskav alternativnih, okoljsko sprejemljivejših pristopov za njegovo zatiranje (Bohinc in sod., 2019; Laznik in sod., 2010), ki vključujejo tudi uporabo insekticidnih proteinov (Alyokhin in sod., 2008; Cingel in sod., 2017).

\section{SKUPINE INSEKTICIDNIH PROTEINOV}

\subsection{RASTLINSKI LEKTINI}

Lektini so proteini neimunskega izvora, ki imajo mesta za specifično vezavo ogljikovih hidratov. Lektini so $\mathrm{v}$ naravi splošno razširjene spojine, večina jih je rastlinskega izvora, najdemo pa jih tudi v različnih vrstah živali, gliv, bakterij in virusov (Peumans in Van Damme, 1995). V rastlinah so koncentracije lektinov navadno največje v semenih in drugih založnih organih, kjer predstavljajo zalogo skladiščih proteinov, sodelujejo pri komunikaciji gostiteljskih rastlin s simbiotskimi mikroorganizmi, kot so bakterije iz rodu Rhizobium in mikorizne glive. Vsebnost lektinov se $\mathrm{v}$ rastlinskih tkivih poveča tudi ob napadu škodljivih organizmov, na podlagi česar so ugotovili njihovo vlogo pri induciranem odzivu rastlin na napad škodljivih organizmov, predvsem žuželk. Povečana vsebnosti lektinov v rastlinskih celicah je pogojena $s$ tvorbo rastlinskih hormonov, ki sprožijo ekspresijo genov za njihovo sintezo ob napadu herbivorov. Lektini, ki jih proizvajajo rastline, se ob zaužitju vežejo s specifičnimi ogljikovimi hidrati, vezanimi $\mathrm{v}$ glikoproteinske in glikolipidne strukture, na peritrofični membrani žuželčjega epitela (Vandenborre in sod., 2011). Zaradi specifičnosti vezave posameznih lektinov je njihov toksični učinek, ki se odraža v omejevanju prehranjevanja, rasti in razvoja ciljnega organizma na posamezne vrste žuželk, nepredvidljiv. Do danes so bili med drugim izolirani številni lektini iz več rastlinskih vrst $\mathrm{z}$ dokazanim toksičnim delovanjem na grizoče žuželke iz reda metuljev (Lepidoptera), polkrilcev (Hemiptera) in hroščev (Coleoptera) (Carlini in Grossi-De-Sá, 2002; Vandenborre in sod., 2011). Prepoznani insekticidno delujoči lektini so bili preizkušeni $\mathrm{v}$ številnih laboratorijskih raziskavah na podlagi lektin-vsebujočih diet in poskusih s transgenimi rastlinami $\mathrm{z}$ vnosi genov, ki kodirajo zapise za njihovo sintezo. Po vsebnosti lektinov so bogata predvsem semena nekaterih vrst stročnic, iz katerih izhaja največ potencialno učinkovitih lektinov, ki so bili preučeni v raziskavah. Prvi so o učinkovitosti lektina PHA, ki so ga izolirali iz semen fižola (Phaseolus vulgaris L.), poročali Gatehouse in sod. (1984) in 
dokazali njegovo toksično delovanje na ličinke hrošča Callosobruchus maculatus (Fabricius, 1775). Poleg stročnic so pozneje proti omenjenemu škodljivcu ugotovili delovanje lektinov iz številnih rastlinskih vrst (Zhu in sod., 1996). Za zatiranje ličink koloradskega hrošča (Leptinotarsa decemlineata [Say, 1824]) so Wang in sod. (2003) v laboratorijskih poskusih pri nanosu na liste dokazali učinkovitost lektina imenovanega gleheda, ki so ga izolirali iz listov bršljanaste grenkuljice (Glechoma hederacea L.). V tej raziskavi nobena od ličink, ki so se prehranjevale na listih krompirja (Solanum tuberosum L.) tretiranih $\mathrm{z}$ lektinom, ni dokončala razvojnega kroga. Obstoj rastlinskih lektinov je znan že stoletja, njihov pomen $\mathrm{v}$ fiziologiji rastlin pa še ni povsem razjasnjen. Dokazano učinkovitost lektinov, izoliranih iz različnih rastlinskih vrst, je pri genski transformaciji in vnosu v ciljne rastline težko predvideti; njihova učinkovitost je lahko vprašljiva tudi zaradi številnih neznank o načinih delovanja proti žuželkam na molekularni ravni (Dang in Van Damme, 2015), slabše pa so preučeni tudi njihovi vplivi na neciljne organizme (Vandenborre in sod., 2011, Dang in Van Damme, 2015).

Glede na strukturo razvrščamo lektine v več različnih skupin, mednje pa uvrščamo tudi t.i. ribosom-inaktivirajoče proteine (RIP), ki s specifično N-glukozidazno aktivnostjo povzročijo deaktivacijo ribosomov (Vandenborre in sod., 2011). Najbolj znan in preučen RIP je ricin, ki so ga najprej izolirali iz kloščevca (Ricinus communis L.) in pozneje iz drugih vrst iz rodu $R i$ cinus. Njegovo toskično delovanje so med drugim ugotovili tudi na hroščih, in sicer na vrstah Callosobruchus maculatus in Anthonomus grandis Boheman, 1843 (Gatehouse in sod., 1984). Do danes so tudi na podlagi analize genomov ugotovili prisotnost drugih RIP sekvenc v številnih drugih rastlinah (Dang in Van Damme, 2015). RIP se sicer za namene žlahtnjenja odpornih sort rastlin redkeje uporabljajo, predvsem zaradi nespecifične toksičnosti za sesalce (Carlini in Grossi-De-Sá, 2002). Nasprotno pa so gene za sintezo nekaterih lektinov iz nerastlinskih virov že vnesli $\mathrm{v}$ rastline, kot na primer gene za sintezo lektinov iz jajčnih beljakov za zatiranje koloradskega hrošča, ki so jih preizkušali v poskusih s transgenimi rastlinami krompirja (Cooper in sod., 2009).

\subsection{INHIBITORJI PREBAVNIH ENCIMOV}

Tako kot ostali heterotrofni organizmi, tudi rastlinojede žuželke za zadovoljevanje svojih energetskih potreb in prebavo rastlinskih tkiv izločajo vrsto prebavnih encimov. Pomembnejši med njimi so proteaze in glikohidrolaze, ki omogočajo razgradnjo molekul beljakovin in sladkorjev v rastlinskem soku. Encimske lastnosti posameznih žuželk so prilagojene njihovemu načinu prehranjevanja ter biokemijskim lastnostim gostiteljskih rastlin.

Inhibitorji prebavnih encimov so snovi, ki predstavljajo pomemben del imunskega odziva rastlin na napad škodljivih organizmov. Nahajajo se v rastlinskem tkivu, pretežno $\mathrm{v}$ semenih in gomoljih, njihova sinteza pa poteka kot del induciranega odziva rastlin na grizenje, bodenje ali sesanje (Ryan, 1990, Fürstenberg-Hägg in sod., 2013).

Različne skupine proteolitičnih encimov ali proteaz v prebavilih žuželk sodelujejo pri presnovi proteinov in zagotavljajo vir aminokislin. Regulacija proteolitske aktivnosti je zaradi vitalne funkcije tega procesa $\mathrm{v}$ organizmih izrednega pomena in poteka tudi na podlagi inhibitorjev, ki z vezavo na specifične katalitične domene proteaz tvorijo komplekse ter onemogočajo njihovo aktivnost (Ryan, 1990). Vloga inhibitorskih proteinov v organizmih je večplastna, različni organizmi, med njimi tudi rastline, jih med drugim tvorijo tudi v obrambne namene. Največ inhibitorjev proteaz tvorijo rastline iz družin metuljnic (Fabaceae), razhudnikovk (Solanaceae) in trav (Poaceae). Iz njihovih tkiv so izolirali številne proteine za inhibicijo specifičnih proteaz, ki jih izločajo žuželke in na podlagi molekularnih tehnik določili gene za njihovo sintezo ter jih vnesli v druge gostiteljske vrste (Dang in Van Damme, 2015; Singh in sod., 2020).

$\mathrm{V}$ prebavilih koloradskega hrošča prevladujejo cisteinske proteaze in aspartatne proteaze, ki jih inhibirajo obrambni aspartatni in cisteinski inhibitorji (cistatini) (Wolfson in Murdock, 1987; Srp in sod., 2016). Na podlagi ugotovitev o akumulaciji inhibitorjev proteaz $\mathrm{v}$ krompirju in paradižniku (Solanum lycopersicum L.) zaradi napada ličink koloradskega hrošča, sta o njihovi vlogi pri razvoju odpornosti sklepala Green in Ryan (1972). Eni izmed prvih cisteinskih inhibitorjev, ki so jih s pomočjo rekombinantne bakterijske RNA uspešno izolirali iz rastlin in preizkusili za namene zatiranja hroščev, so bili cistatini iz riža (Oryza sativa L.) - orizacistatini (Chen in sod., 1992). Leto pozneje so Michaud in sod. (1993) dokazali specifičnost njihove vezave na cisteine, ki so jih izolirali iz prebavil koloradskega hrošča. Na podlagi vnosa orizacistatinov v krompir so te preizkusili za namene zatiranja koloradskega hrošča in ugotovili vpliv na povečanje smrtnosti ličink (Lecardonnel in sod., 1999; Cingel in sod., 2017). Podobne učinke na zmanjšanje rasti ličink so ugotovili tudi pri vnosu inhibitorjev cistatinov iz papaje (Carica papaya L.), soje (Glycine max [L.] Merr.) in ječmena (Hordeum vulgare L.) (Visal in sod., 1998; Lalitha in sod., 2005; Álvarez-Alfageme in sod., 2007). Ashouri in sod. (2017) so inhibitorje cisteinov koloradskega hrošča določili tudi v 
semenih sončnic (Helianthus annuus L.).

Iz prebavil koloradskega hrošča so izolirali tudi aspartatne proteaze, njihove inhibitorje pa so odkrili v paradižniku. Po uspešnem vnosu $\mathrm{v}$ rastline krompirja so preizkušali njihovo pot ${ }^{\mathrm{e}}$ cialno učinkovitost in ugotovili številne fiziološke posledice za ličinke L3 stopnje koloradskega hrošča, ki so se odražale v manjši ješčnosti, masi in prirastu, medtem ko pri starejših ličinkah (stopnja L4) tega učinka niso zaznali (Brunelle in sod., 2004). O podobnem fenomenu prilagoditve koloradskega hrošča so poročali že Cloutier in sod. (2000), ki pri proučevanju orizacistatinov niso ugotovili predhodno dokazano učinkovitega delovanja na odrasle hrošče.

Znano je namreč, da naštete načine encimske inhibicije $\mathrm{v}$ rastlinah žuželke zaradi izdatnejših potreb po aminokislinah in posledičnega selekcijske pritiska, s prilagoditvami encimske aktivnost hitro zaobidejo. Žuželke se na nove prehrambene razmere prilagodijo na različne načine, kot so hiperprodukcija proteaz in povečano prehranjevanje $\mathrm{z}$ gostiteljskim tkivom, sintezo novih odpornih proteaz in proteolitsko deaktivacijo rastlinskih inhibitorjev (Ryan, 1990; Cingel in sod., 2016). Podrobneje so mehanizme prilagoditve koloradskega hrošča na proteolitsko inhibicijo, ki se odraža v spremembah sinteze cisteinov, preučevali Gruden in sod. (2004).

Naprednejši biotehnološki pristopi vključujejo tehnike t.i. piramidenja genov, kjer $\mathrm{z}$ vnosom več sekvenc omogočajo izražanje različnih tipov inhibitorjev in s tem manjšo možnost razvoja odpornosti škodljivih organizmov (Schlüter in sod., 2010; Martinez in sod., 2016). Učinkovitost takšnega pristopa so na podlagi koekspresije genov za sintezo dveh različnih cistantinov v krompirju, dokazali tudi Cingel in sod. (2017) pri zatiranju koloradskega hrošča.

Inhibitorje proteaz, ki sodelujejo $\mathrm{v}$ metabolizmu koloradskih hroščev, pa so $\mathrm{v}$ preteklih raziskavah izolirali tudi iz drugih nerastlinskih virov. Gruden in sod. (1998) so ugotovili toksično delovanje cistatinov iz rdeče morske vetrnice (Actinia equina (L., 1758).

Encimi imajo odločilno vlogo tudi pri metabolizmu ogljikovih hidratov. Alfa amilaze ( $\alpha$ amilaze) so hidrolitični encimi, ki so zastopani v živalih, rastlinah in mikroorganizmih. Ti encimi katalizirajo hidrolizo glikozidnih vezi polisaharidov in imajo pomembno vlogo pri razgradnji kompleksnih sladkorjev, kot sta škrob in glikogen. Predvsem za žuželke, ki se pretežno prehranjujejo s semeni, torej rastlinskimi organi $\mathrm{z}$ veliko vsebnostjo škroba, je aktivnost a amilaze odločilna za njihovo preživetje (Franco in sod., 2002). Rastline se tudi na žuželčje a amilaze odzivajo s sintezo specifičnih inhibitorjev $\mathrm{z}$ različnimi mehanizmi inhibicije, ki se odraža $\mathrm{v}$ zmanjšanju metabolizma ogljikovih hidratov kot pomembnega vira energije. Večja vsebnost inhibitorjev je značilna predvsem za semena žit in stročnic (Carlini in Grossi-De-Sá, 2002; Fürstenberg-Hägg in sod., 2013). $\mathrm{V}$ več raziskavah so ugotovili učinkovitost inhibitorjev iz pšenice (Triticum aestivum L.), ječmena, riža, koruze (Zea mays L.) in več rastlinskih vrst iz družine ščirovk (Amaranthaceae) za zaviranje aktivnosti $\alpha$ amilaz različnih skladiščnih škodljivcev, kot so mokarji (Tribolium spp.), žitni žužki iz rodu Sitophilus ter žitniki iz rodu Oryzaephilus (Fürstenberg-Hägg in sod., 2013; Rane in sod., 2020). Natančneje so bili preučeni tudi različni inhibitorji a amilaz iz fižola za zatiranje nekaterih lepencev iz poddružine Bruchinae, ki povzročajo škodo na semenih stročnic (Carlini in Grossi-De-Sá, 2002; Rane in sod., 2020). Ashouri in sod. (2017) so iz rdečega fižola izolirali tudi inhibitorje, ki so $\mathrm{v}$ prehranjevalnih testih vplivali na zmanjšano aktivnost a amilaz ličink koloradskega hrošča (Ashouri in Farshbaf Pourabad, 2021).

\subsection{BAKTERIJSKI INSEKTICIDNI PROTEINI}

Bakterijski toksini so najpogosteje uporabljene mikrobne učinkovine pri zatiranju rastlinskih škodljivcev. Do sedaj je bilo odkritih več kot sto različnih vrst bakterij, ki izkazujejo entomopatogeno delovanje, med njimi predvsem bakterije iz družin Bacillaceae, Pseudomonadaceae, Enterobacteriaceae, Streptococcaceae in Micrococcaceae (Kalha in sod., 2014). Izmed bakterijskih insekticidih proteinov so najbolje preučeni in $\mathrm{v}$ najširši uporabi $\delta$ toksini, ki jih proizvaja gram pozitivna bakterija Bacillus thuringiensis Berliner, 1915, Bt. Pomembnejši med njimi so Cry toksini, ki izkazujejo toksično delovanje na vrsto žuželk, med drugim tudi na hrošče. Bt proizvaja Cry toksine v času sporulacije in jih kopiči v obliki kristalnih struktur (Crickmore in sod., 1998). Cry toksine uvrščamo v skupino t. i. porotvornih toksinov (PFT), za katere je značilna afiniteta vezave na biološke membrane in tvorba transmembranskih por. Po zaužitju kristalnih struktur se namreč pod vplivom nizkega $\mathrm{pH}$ prebavnih sokov in proteazne aktivnosti $\mathrm{v}$ črevesju gostitelja iz njih sprostijo toksini, ki z vezavo na specifične proteinske receptorje in povzročanjem poškodb na membranah povzročijo celično smrt ter s tem zmanjšano prehranjevalno sposobnost žuželk, ki posledično odmrejo (Bravo in sod., 2007). Zanje je značilno visoko specifična insekticidna učinkovitost oz. delovanje zgolj na določene vrste oziroma skupine žuželk, ki je pogojena $\mathrm{z}$ biokemično strukturo in metabolno aktivnostjo ciljnega organizma. Bt toksini niso strupeni za vretenčarje in rastline ter so popolnoma biorazgradljivi, zaradi česar so še posebno zanimivi za uporabo v varstvu rastlin (Palma in sod., 2014). Trenu- 
tna Bt nomenklatura obsega več sto sekvenc za sintezo različnih proteinov, med njimi je največja skupina Cry3, iz katerih izhaja največ bakterijskih toksinov, ki so toksični za žuželke (Berry in Crickmore, 2017). Izmed proteinov iz te skupine izhaja največ toksinov, ki izkazujejo insekticidno delovanje na koloradskega hrošča, predvsem Cry3A in Cry3B, ki so bili največkrat vneseni $v$ transformirane rastline krompirja. Prav transgena sorta krompirja ,NewLeaf' (Monsanto Corp.), v katero so vnesli Cry3A, z namenom povečevanja odpornosti proti koloradskemu hrošču, velja za prvo komercialno gensko spremenjeno sorto rastline, ki je bila v Združenih državah Amerike registrirana leta 1995 za pridelavo $\mathrm{v}$ prehrambne namene. Reed in sod. (2001) so v dveletnem poljskem poskusu dokazali primerljivo učinkovitost uporabe sorte ,NewLeaf' kot načina varstva pred koloradskim hroščem z manj negativnimi vplivi na neciljne organizme $\mathrm{v}$ primerjavi z rabo insekticidov. Kljub vsemu je bila omenjena sorta pozneje zaradi splošno negativnega javnega mnenja glede uporabe gensko spremenjenih rastlin umaknjena s tržišča (Grafius in Douches, 2008). Razvoj in pridelava sort na podlagi Cry3A se predvsem zaradi naraščajoče problematike razvoja odpornosti koloradskega hrošča proti insekticidom in trendov zmanjševanja negativnih vplivov kmetijske pridelave na okolje nadaljuje tudi drugod po svetu (Kamionskaya in sod., 2012; Mi in sod., 2015; K. Wang in sod., 2019). Do danes so v številnih raziskavah potrdili insekticidno delovanje na koloradskega hrošča tudi pri toksinih iz drugih skupin Cry proteinov, kot so Cry1, Cry2, Cry3, Cry5, Cry7 in Cry8 (K. Wang in sod., 2019; Balaško in sod., 2020; Domínguez-Arrizabalaga in sod., 2020).

Bt, poleg endogenih Cry toksinov, proizvajajo tudi druge proteine $\mathrm{z}$ insekticidnim delovanjem na hrošče, ki jih $\mathrm{v}$ medcelični prostor izločajo $\mathrm{v}$ fazi vegetativne oblike. Vip1 in Vip2 toksini se podobno kot Cry vežejo na prebavni epitel žuželk in ga poškodujejo (Chakroun in sod., 2016). Znani so tudi Sip toksini, ki se uvrščajo v skupino t. i. sekrecijskih proteinov, in jih bakterije izločajo v svojo okolico. Izmed slednjih toksin tipa Sip1A, ki ga izloča $\mathrm{Bt}$, dokazano učinkuje tudi proti ličinkam koloradskega hrošča (Donovan in sod., 2006).

Poleg Bt so vir proteinov $\mathrm{z}$ insekticidnim delovanjem na koloradskega hrošča našli še v nekaterih drugih vrstah bakterij, kot na primer v Chromobacterium sp. (Martin in sod., 2006), Photorhabdus luminescens, Photorhabdus luminescens (Thomas and Poinar, 1979) Boemare et al., 1993 emend. Fischer-Le Saux et al., 1999 (Blackburn in sod., 2005) in Leclercia adecarboxylata (Leclerc 1962) (Muratoglu in sod., 2011). Toksini iz drugih vrst bakterij lahko predstavljajo pomemben potencial za uporabo pri genski transformaciji, tudi kot nadomestilo za Bt proteine $\mathrm{v}$ smislu preprečevanja razvoja odpornosti koloradskega hrošča proti Cry toksinom (Wang in sod., 2019). Žuželke namreč pod vplivom selekcijskega pritiska s fiziološkimi prilagoditvami, ki omogočajo razgradnjo ali deaktivacijo specifičnih proteinskih toksinov ali mutacijami receptorjev na prebavnem epitelu, spontano razvijajo odpornost na Cry toksine (Bravo in sod., 2011). Iz preteklosti so znani nekateri primeri populacij koloradskega hrošča, odpornih proti Cry3A proteinom (Whalon in sod., 1993). $\mathrm{V}$ primeru širše uporabe Bt sort krompirja pa je moč pričakovati, da bi ta problematika lahko postala pereč problem (Domínguez-Arrizabalaga in sod., 2020).

Varstvo pred rastlinskimi škodljivci na podlagi bakterijskih proteinov poleg razvoja transgenih rastlin temelji tudi na njihovi uporabi v obliki mikrobnih bioinsekticidov, namenjenih nanosu s pršenjem. Prav pripravki na podlagi Bt toksinov so glavno gonilo razvoja bioinsekticidov, njihov tržni odstotek na globalnem trgu tovrstnih proizvodov pa naj bi dosegal skoraj $90 \%$ (Jallouli in sod., 2020). Večina Bt insekticidov vsebuje Cry3 kristalne strukture, ki se jih v vodni raztopini na rastline nanaša foliarno. Za zatiranje ličink koloradskega hrošča je znana uporaba Cry3A, ki ga proizvaja $B t$ subsp. tenebrionis in je na trgu dostopen v obliki komercialnega proizvoda Novodor (Domínguez-Arrizabalaga in sod., 2020). Takšen način uporabe bakterijskih proteinov je v praksi bolj uveljavljen, saj je uvajanje pridelave gensko spremenjenih rastlin predvsem v Evropi še vedno zelo striktno regulirano in večinoma prepovedano (Direktiva EU 2001/18/ES). Kljub učinkovitemu delovanju Bt pripravkov je slabost foliarnega nanosa Cry proteinov, $\mathrm{v}$ primerjavi $\mathrm{z}$ izražanjem $\mathrm{v}$ transformiranih rastlinah, njihova omejena učinkovitost, ki je posledica vpliva okoljskih dejavnikov, predvsem podvrženosti proteinov svetlobni razgradnji zaradi UV svetlobe (Bravo in sod., 2011).

\subsection{PROTEINI IZ GOB}

Višje glive (Eumycota) iz dveh različnih debel, in sicer prostotrosnice (Basidiomycota) ter zaprtotrosnice (Ascomycota), na nadzemskem delu tvorijo reprodukcijske organe - trosišča, ki jim pravimo gobe. Z njimi se v naravi hranijo številni fungivori, med njimi tudi žuželke. Glive so med evolucijo razvile različne obrambne mehanizme, ki gobe varujejo pred fungivori, saj je s tem pogojena njihova zmožnost razmnoževanja. Večina obrambnih procesov temelji na tvorbi proteinov, med katerimi so številni toksični tudi za žuželke (Wang in sod., 2002).

Za glive je značilna velika vsebnost lektinov, ki 
predstavljajo pomemben vir založnih beljakovin, imajo pomembno vlogo $\mathrm{v}$ simbiotskih in parazitskih odnosih ter sodelujejo pri obrambnih odzivih na napad škodljivih organizmov. Glede na strukturo lektine iz gob razvrščamo v šest različnih skupin; pri nekaterih so ugotovili njihove toksične učinke na nekatere vrste žuželk (Varrot in sod., 2013). Lektin, ki so ga izolirali iz glive Rhizoctonia solani J.G. Kühn, spada v skupino hololektinov. Le-ti imajo podobne strukturne in sekvenčne lastnosti kot rastlinski lektin ricin. Walski in sod. (2014) so $\mathrm{v}$ poskusih ugotovili njegov vpliv na zmanjšano rast in upočasnjen razvoj ličink riževega mokarja (Tribolium castaneum [Herbst, 1797]). Pohleven in sod. (2011) so preučevali insekticidni učinek lektinov iz poprhnjene livke (Clitocybe nebularis [Batsch] P. Kumm., CNL), pri čemer so ugotovili, da je uporaba lektina CNL vplivala na zmanjšanje prehranjevanja ličink koloradskega hrošča. Vse omenjene raziskave toksičnih lektinov iz gliv na žuželke so bile opravljene laboratorijsko na podlagi prehranskih testov; poskusi s transgenimi rastlinami še niso bili opravljeni.

Gobe so bogat vir proteinov in proteaznih inhibitorjev. Zlasti iz gliv iz debla prostotrosnic so izolirali številne inhibitorje proteolize, ki so jim natančneje določili pomembne biokemične in strukturne lastnosti, po katerih se ločijo od inhibitorjev proteaz iz drugih virov (Erjavec in sod., 2012; Sabotič in Kos, 2012). Pri tem gre pretežno za serinske (mikospini) in cisteinske (mikocipini) inhibitorje, ki izkazujejo tudi insekticidne lastnosti (Sabotič in sod., 2016). Makrocipini iz skupine mikocipinskih inhibitorjev žuželčjih cisteinov, ki so jih izolirali iz orjaškega dežnika (Macrolepiota procera [Scop.] Singer), so v prehranjevalnih testih povzročili zmanjšanje rasti ličink koloradskega hrošča, njihov insekticidni učinek pa je bil dokazan tudi v transgenih rastlinah krompirja (Šmid in sod., 2013). Šmid in sod. (2015) so v prehranjevalnih testih ugotovili tudi toksični vpliv klitocipina iz poprhnjene livke, ki je povzročil večjo smrtnost ličink, vendar je v transgenem krompirju zaradi manjšega izražanja genov izkazoval manjšo insekticidno učinkovitost $\mathrm{v}$ primerjavi $\mathrm{z}$ makrocipinom.

\subsection{EGEROLIZINI}

Proteini iz družine egerolizinov sodijo v skupino porotvornih proteinov, ki jih proizvajajo različni evkariontski organizmi ter bakterije. Njihova biološka vloga še ni povsem razjasnjena, znana pa je njihova velika afiniteta vezave na membranske lipide in sposobnost tvorbe transmembranskih por (Berne in sod., 2009; Butala in sod., 2017). Bakterijski egerolizini različnih virov se znotraj večkomponentnih kompleksov speci- fično vežejo v prebavilih žuželk in nanje delujejo toksično. Glede na strukturo med egerolizine uvrščamo tudi nekatere Cry proteine, ki jih tvori Bt. Za binarni kompleks Cry34Ab1 / Cry35Ab1 je značilna specifična vezava v prebavnem epitelu koruznega hrošča (Diabrotica virgifera virgifera LeConte, 1868) in tvorba transmembranskih por. Omenjeni kompleks so na podlagi transformacije vnesli $\mathrm{v}$ hibrid koruze, ki je na voljo $\mathrm{v}$ komercialni pridelavi. Večina študij se sicer osredotoča predvsem na preučevanje egerolizinov iz gob, med katerimi imajo številni tudi insekticidne lastnosti. Za egerolizine, ki jih tvorijo glive iz rodu ostrigarjev (Pleurotus sp.), je značilna specifična vezava $\mathrm{z}$ lipidom, in sicer s sfingolipidom ceramid fosfoetanolaminom, ki je prisoten $\mathrm{v}$ membranah nevretenčarjev, ni pa ga $\mathrm{v}$ vretenčarjih. Omenjena lastnost pogojuje perspektivnost nadaljnih raziskav njihove uporabe za proizvodnjo selektivnih insekticidov. Insekticidno delovanje egerolizinov iz ostrigarjev omogoča vezava $\mathrm{v}$ proteinske komplekse s partnerskimi proteini, ki vsebujejo specifične MACPF (angl. membrane attack complex/perforin) domene, ki tvorijo transmembranske pore (Butala in sod., 2017; Panevska in sod., 2020). Panevska in sod. (2019) so $\mathrm{v}$ raziskavi med drugim preučevali tudi toksičnost egerolizinskih kompleksov iz ostrigarjev proti ličinkam koloradskega hrošča. Določili so tri egerolizinske proteine: ostreolizin A6 (OlyA6), pleurotolizin A2 (PlyA2) in erilizin A (EryA). Ti skupaj s partnerskim proteinom pleurotolizinom B (PlyB) tvorijo transmembranske pore $\mathrm{v}$ črevesnih celicah, kar se odraža $\mathrm{v}$ povečani smrtnosti ličink zaradi stradanja. Rezultati nakazujejo nadaljnjo možnost uporabe egerolizinskih kompleksov iz ostrigarjev kot bioinsekticidnih komponent ali virov odpornosti proti koloradskemu hrošču pri žlahtnjenju rastlin.

\section{SKLEPI}

Insekticidno delujoči proteini, ki jih tvorijo različne vrste organizmov, predstavljajo pomemben potencial $\mathrm{v}$ varstvu rastlin pred škodljivci. V primerjavi s sintetičnimi insekticidi je njihova prednost bolj specifično delovanje, hitra razgradnja in manjša toksičnost za neciljne organizme. Razvoj odpornih sort rastlin je eden glavnih žlahtniteljskih ciljev, ki ga lažje dosegajo $\mathrm{z}$ uporabo sodobnih biotehnoloških postopkov in proizvodnje gensko spremenjenih rastlin.

Škodljivci se tekom generacij relativno hitro prilagajajo na spremenjene okoljske razmere in oblikujejo nove obrambne mehanizme. Kljub temu so za preprečevanje razvoja odpornosti pomembna preučevanja in raziskave drugih vrst insekticidih proteinov iz različ- 
nih virov. Sodobni biotehnološki pristopi omogočajo hkraten vnos dveh ali več genov iz različnih virov za sintezo proteinov z različnimi načini delovanja (piramidenje genov) ali fuzijo gena, ki sočasno kodira dva proteina (fuzijski proteini). Takšen način proizvodnje transgenih rastlin omogoča zanesljivejšo in dolgotrajnejšo učinkovitost proti kateri škodljivi organizmi težje razvijejo odpornost.

Izmed proteinov, ki izkazujejo insekticidno delovanje, so najbolj preučeni bakterijski proteini, med njimi predvsem Cry proteini, ki jih proizvaja Bt. Geni za njihovo sintezo so največkrat uporabljeni pri transformaciji $\mathrm{v}$ rastlinska tkiva za namene razvoja odpornih sort rastlin. Pridelava transgenih sort krompirja odpornih na koloradskega hrošča trenutno v praksi ni razširjena, kljub temu pa potekajo številne raziskave vnosa insekticidno delujočih proteinov iz različnih virov, ki v laboratorijskih razmerah izkazujejo učinkovitost pri zatiranju tega škodljivca.

Zaradi splošnih zadržkov javnosti in zakonodaje proti uveljavljanju gensko spremenjenih rastlin $\mathrm{v}$ kmetijstvu, je pomemben razvoj drugih možnosti uporabe insekticidnih proteinov, predvsem $\mathrm{v}$ obliki bioinsekticidov. Tudi tukaj prednjači uporaba Bt formulacij, njihova uporaba pa je $\mathrm{v}$ zadnjih 30 letih $\mathrm{v}$ porastu tudi zaradi tendence po zmanjševanju uporabe kemičnih insekticidov. Uporaba bioinsekticidov predstavlja pomembno alternativo kemičnim insekticidom tudi pri zatiranju koloradskega hrošča. Proti njegovim ličinkam delujejo toksini, ki jih izloča Bt subsp. tenebrionis, pomembno vlogo pri razvoju novih insekticidnih učinkovin pa imajo tudi proteini iz drugih virov. Predvsem višje glive predstavljajo pomemben vir lektinov, encimskih inhibitorjev in egerolizinov, ki delujejo toksično na ličinke koloradskega hrošča in številne druge žuželke.

\section{VIRI}

Álvarez-Alfageme, F., Martínez, M., Pascual-Ruiz, S., Castañera, P., Diaz, I., Ortego, F. (2007). Effects of potato plants expressing a barley cystatin on the predatory bug Podisus maculiventris via herbivorous prey feeding on the plant. Transgenic Research, 16(1), 1-13. https://doi.org/10.1007/ s11248-006-9022-6

Alyokhin, A., Baker, M., Mota-Sanchez, D., Dively, G., Grafius, E. (2008). Colorado potato beetle resistance to insecticides. American Journal of Potato Research, 85(6), 395-413. https://doi.org/10.1007/s12230-008-9052-0

Ashouri, S., Farshbaf Pourabad, R. (2021). Regulation of gene expression encoding the digestive $\alpha$-amylase in the larvae of Colorado potato beetle, Leptinotarsa decemlineata (Say) in response to plant protein extracts. Gene, 766, 145159. https://doi.org/10.1016/j.gene.2020.145159
Ashouri, S., Farshbaf Pourabad, R., Kocadağ Kocazorbaz, E., Zihnioglu, F. (2017). Influence of red kidney bean seed proteins on development, digestive a-amylase activity and gut protein pattern of Leptinotarsa decemlineata (Say). Journal of the Entomological Research Society, 19(3), 69-83.

Balaško, M. K., Mikac, K. M., Bažok, R., Lemic, D. (2020). Modern techniques in colorado potato beetle (Leptinotarsa decemlineata Say) control and resistance management: History review and future perspectives. Insects, 11(9), 1-17. https://doi.org/10.3390/insects11090581

Berne, S., Lah, L., Sepčić, K. (2009). Aegerolysins: Structure, function, and putative biological role. Protein Science, 18(4), 694-706. https://doi.org/10.1002/pro.85

Berry, C., Crickmore, N. (2017). Structural classification of insecticidal proteins - Towards an in silico characterisation of novel toxins. Journal of Invertebrate Pathology, 142, 16-22. https://doi.org/10.1016/j.jip.2016.07.015

Blackburn, M. B., Domek, J. M., Gelman, D. B., Hu, J. S. (2005). The broadly insecticidal Photorhabdus luminescens toxin complex a (Tca): Activity against the Colorado potato beetle, Leptinotarsa decemlineata, and sweet potato whitefly, Bemisia tabaci. Journal of Insect Science, 5. https://doi. org/10.1093/jis/5.1.32

Bohinc, T., Vučajnk, F., Trdan, S. (2019). The efficacy of environmentally acceptable products for the control of major potato pests and diseases. Zemdirbyste-Agriculture, 106(2), 135-142. https://doi.org/10.13080/z-a.2019.106.018

Bravo, A., Gill, S. S., Soberón, M. (2007). Mode of action of Bacillus thuringiensis Cry and Cyt toxins and their potential for insect control. Toxicon: official journal of the International Society on Toxinology, 49(4), 423-435. https://doi. org/10.1016/j.toxicon.2006.11.022

Bravo, A., Likitvivatanavong, S., Gill, S. S., Soberón, M. (2011). Bacillus thuringiensis: A story of a successful bioinsecticide. Insect Biochemistry and Molecular Biology, 41(7), 423431. https://doi.org/10.1016/j.ibmb.2011.02.006

Brunelle, F., Cloutier, C., Michaud, D. (2004). Colorado potato beetles compensate for tomato cathepsin D inhibitor expressed in transgenic potato. Archives of Insect Biochemistry and Physiology, 55(3), 103-113. https://doi. org/10.1002/arch.10135

Butala, M., Novak, M., Kraševec, N., Skočaj, M., Veranič, P., Maček, P., Sepčić, K. (2017). Aegerolysins: Lipid-binding proteins with versatile functions. Seminars in Cell and Developmental Biology, 72, 142-151). https://doi. org/10.1016/j.semcdb.2017.05.002

Carlini, C. R., Grossi-De-Sá, M. F. (2002). Plant toxic proteins with insecticidal properties. A review on their potentialities as bioinsecticides. Toxicon, 40(11), 1515-1539. https:// doi.org/10.1016/S0041-0101(02)00240-4

Chakroun, M., Banyuls, N., Bel, Y., Escriche, B., Ferré, J. (2016). Bacterial Vegetative Insecticidal Proteins (Vip) from Entomopathogenic Bacteria. Microbiology and Molecular Biology Reviews, 80(2), 329 LP - 350. https://doi.org/10.1128/ MMBR.00060-15

Chen, M. S., Johnson, B., Wen, L., Muthukrishnan, S., Kramer, K. J., Morgan, T. D., Reeck, G. R. (1992). Rice cystatin: Bacterial expression, purification, cysteine proteinase inhibitory activity, and insect growth suppressing activity 
of a truncated form of the protein. Protein Expression and Purification, 3(1), 41-49. https://doi.org/10.1016/10465928(92)90054-Z

Cingel, A., Savić, J., Lazarević, J., Ćosić, T., Raspor, M., Smigocki, A., Ninković, S. (2016). Extraordinary adaptive plasticity of colorado potato beetle: "Ten-striped Spearman" in the era of biotechnologicalwarfare. International Journal of Molecular Sciences, 17(9). MDPI AG. https://doi. org/10.3390/ijms17091538

Cingel, A., Savić, J., Lazarević, J., Ćosić, T., Raspor, M., Smigocki, A., Ninković, S. (2017). Co-expression of the proteinase inhibitors oryzacystatin I and oryzacystatin II in transgenic potato alters Colorado potato beetle larval development. Insect Science, 24(5), 768-780. https://doi. org/https://doi.org/10.1111/1744-7917.12364

Cloutier, C., Jean, C., Fournier, M., Yelle, S., Michaud, D. (2000). Adult Colorado potato beetles, Leptinotarsa decemlineata compensate for nutritional stress on oryzacystatin I-transgenic potato plants by hypertrophic behavior and over-production of insensitive proteases. Archives of Insect Biochemistry and Physiology, 44(2), 69-81. https://doi.org/10.1002/1520-6327(200006)44:2<69::AID$\mathrm{ARCH} 2>3.0 . \mathrm{CO} ; 2-6$

Cooper, S. G., Douches, D. S., Grafius, E. J. (2009). Combining engineered resistance, avidin, and natural resistance derived from \& lt; I \& gt; Solanum chacoense \& lt;/I \& gt; bitter to control Colorado potato beetle (Coleoptera: Chrysomelidae). Journal of Economic Entomology, 102(3), 1270-1280. https://doi.org/10.1603/029.102.0354

Crickmore, N., Zeigler, D. R., Feitelson, J., Schnepf, E., Van Rie, J., Lereclus, D., Baum, J., Dean, D. H. (1998). Revision of the nomenclature for the Bacillus thuringiensis pesticidal crystal proteins. Microbiology and Molecular Biology Reviews, 62(3), 807-813. https://doi.org/10.1128/ mmbr.62.3.807-813.1998

Dang, L., Van Damme, E. J. M. (2015). Toxic proteins in plants. Phytochemistry, 117(1), 51-64). https://doi.org/10.1016/j. phytochem.2015.05.020

Domínguez-Arrizabalaga, M., Villanueva, M., Escriche, B., Ancín-Azpilicueta, C., Caballero, P. (2020). Insecticidal activity of Bacillus thuringiensis proteins againstcoleopteran Pests. Toxins, 12(7), 430. https://doi.org/10.3390/ toxins12070430

Donovan, W. P., Engleman, J. T., Donovan, J. C., Baum, J. A., Bunkers, G. J., Chi, D. J., Clinton, W. P., English, L., Heck, G. R., Ilagan, O. M., Krasomil-Osterfeld, K. C., Pitkin, J. W., Roberts, J. K., Walters, M. R. (2006). Discovery and characterization of Sip1A: A novel secreted protein from Bacillus thuringiensis with activity against coleopteran larvae. Applied Microbiology and Biotechnology, 72(4), 713-719. https://doi.org/10.1007/s00253-006-0332-7

Erjavec, J., Kos, J., Ravnikar, M., Dreo, T., Sabotič, J. (2012). Proteins of higher fungi - from forest to application. Trends in Biotechnology, 30(5), 259-273. https://doi.org/10.1016/j. tibtech.2012.01.004

Franco, O. L., Rigden, D. J., Melo, F. R., Grossi-de-Sá, M. F. (2002). Plant $\alpha$-amylase inhibitors and their interaction with insect a-amylases. European Journal of Biochemistry,
269(2), 397-412. https://doi.org/https://doi.org/10.1046/ j.0014-2956.2001.02656.x

Fürstenberg-Hägg, J., Zagrobelny, M., Bak, S. (2013). Plant defense against insect herbivores. International Journal of Molecular Sciences, 14(5), 10242-10297. https://doi. org/10.3390/ijms 140510242

Gatehouse, A. M. R., Dewey, F. M., Dove, J., Fenton, K. A., Pusztai, A. (1984). Effect of seed lectins from Phaseolus vulgaris on the development of larvae of Callosobruchus maculatus; mechanism of toxicity. Journal of the Science of Food and Agriculture, 35(4), 373-380. https://doi.org/ https://doi.org/10.1002/jsfa.2740350402

Grafius, E. J., Douches, D. S. (2008). The present and future role of insect-resistant genetically modified potato cultivars in IPM. V Integration of Insect-Resistant Genetically Modified Crops within IPM Programs (str. 195-221). Springer Netherlands. https://doi.org/10.1007/978-1-4020-8373-0_7

Green, T. R., Ryan, C. A. (1972). Wound-induced proteinase inhibitor in plant leaves: A possible defense mechanism against insects. Science, 175(4023), 776-777. https://doi. org/10.1126/science.175.4023.776

Gruden, K., Kuipers, A. G. J., Gunčar, G., Slapar, N., Štrukelj, B., Jongsma, M. A. (2004). Molecular basis of Colorado potato beetle adaptation to potato plant defence at the level of digestive cysteine proteinases. Insect Biochemistry and Molecular Biology, 34(4), 365-375. https://doi.org/10.1016/j. ibmb.2004.01.003

Gruden, K., Štrukelj, B., Popovič, T., Lenarčič, B., Bevec, T., Brzin, J., Kregar, I., Herzog-Velikonja, J., Stiekema, W. J., Bosch, D., Jongsma, M. A. (1998). The cysteine protease activity of Colorado potato beetle (Leptinotarsa decemlineata Say) guts, which is insensitive to potato protease inhibitors, is inhibited by thyroglobulin type- 1 domain inhibitors. Insect Biochemistry and Molecular Biology, 28(8), 549-560. https://doi.org/10.1016/S0965-1748(98)00051-4

Jallouli, W., Driss, F., Fillaudeau, L., Rouis, S. (2020). Review on biopesticide production by Bacillus thuringiensis subsp. kurstaki since 1990: Focus on bioprocess parameters. V Process Biochemistry (Let. 98, str. 224-232). Elsevier Ltd. https://doi.org/10.1016/j.procbio.2020.07.023

Kalha, C. S., Singh, P. P., Kang, S. S., Hunjan, M. S., Gupta, V., Sharma, R. (2014). Entomopathogenic viruses and bacteria for insect-pest control. V Integrated Pest Management: Current Concepts and Ecological Perspective (str. 225-244). Elsevier Inc. https://doi.org/10.1016/B978-0-12-3985293.00013-0

Kamionskaya, A. M., Kuznetsov, B. B., Ismailov, V. Y., Nadikta, V. D., Skryabin, K. G. (2012). Genetically transforming Russian potato cultivars for resistance to Colorado beetle. Clon Transgen, 1, 101. https://doi.org/10.4172/21689849.1000101

Lalitha, S., Shade, R. E., Murdock, L. L., Bressan, R. A., Hasegawa, P. M., Nielsen, S. S. (2005). Effectiveness of recombinant soybean cysteine proteinase inhibitors against selected crop pests. Comparative Biochemistry and Physiology - C Toxicology and Pharmacology, 140(2), 227-235. https://doi. org/10.1016/j.cca.2005.02.007

Laznik, Ž., Tóth, T., Lakatos, T., Vidrih, M., Trdan, S. (2010). Control of the Colorado potato beetle (Leptinotarsa de- 
cemlineata [Say]) on potato under field conditions: a comparison of the efficacy of foliar application of two strains of Steinernema feltiae (Filipjev) and spraying with thiametoxam. Journal of Plant Diseases and Protection, 117(3), 129-135. https://doi.org/10.1007/BF03356348

Lecardonnel, A., Chauvin, L., Jouanin, L., Beaujean, A., Prévost, G., Sangwan-Norreel, B. (1999). Effects of rice cystatin I expression in transgenic potato on Colorado potato beetle larvae. Plant Science, 140(1), 71-79. https://doi. org/10.1016/S0168-9452(98)00197-6

Martin, P. A. W., Blackburn, M., Shropshire, A. D. S. (2006). Two new bacterial pathogens of Colorado potato beetle (Coleoptera: Chrysomelidae). Journal of Economic Entomology, 97(3), 774-780. https://doi.org/10.1603/00220493(2004)097[0774:tnbpoc]2.0.co;2

Martinez, M., Santamaria, M. E., Diaz-Mendoza, M., Arnaiz, A., Carrillo, L., Ortego, F. (2016). Phytocystatins: Defense proteins against phytophagous insects and acari. International Journal of Molecular Sciences, 17(10). MDPI AG. https://doi.org/10.3390/ijms17101747

Mi, X., Ji, X., Yang, J., Liang, L., Si, H., Wu, J., Zhang, N., Wang, D. (2015). Transgenic potato plants expressing cry3A gene confer resistance to Colorado potato beetle. Comptes Rendus - Biologies, 338(7), 443-450. https://doi.org/10.1016/j. crvi.2015.04.005

Michaud, D., Nguyen-Quoc, B., Yelle, S. (1993). Selective inhibition of Colorado potato beetle cathepsin $\mathrm{H}$ by oryzacystatins I and II. FEBS Letters, 331(1-2), 173-176. https:// doi.org/10.1016/0014-5793(93)80320-T

Michiels, K., Van Damme, E. J. M., Smagghe, G. (2010). Plantinsect interactions: what can we learn from plant lectins? Archives of Insect Biochemistry and Physiology, 73(4), 193212. https://doi.org/https://doi.org/10.1002/arch.20351

Muratoglu, H., Demirbag, Z., Sezen, K. (2011). The first investigation of the diversity of bacteria associated with Leptinotarsa decemlineata (Coleoptera: Chrysomelidae). Biologia, 66(2), 288-293. https://doi.org/10.2478/s11756011-0021-6

Palma, L., Muñoz, D., Berry, C., Murillo, J., Caballero, P., Caballero, P. (2014). Bacillus thuringiensis toxins: An overview of their biocidal activity. Toxins, 6(12), 3296-3325). MDPI AG. https://doi.org/10.3390/toxins6123296

Panevska, A., Hodnik, V., Skočaj, M., Novak, M., Modic, Š., Pavlic, I., Podržaj, S., Zarić, M., Resnik, N., Maček, P., Veranič, P., Razinger, J., Sepčić, K. (2019). Pore-forming protein complexes from Pleurotus mushrooms kill western corn rootworm and Colorado potato beetle through targeting membrane ceramide phosphoethanolamine. Scientific Reports, 9(1). https://doi.org/10.1038/s41598-019-41450-4

Panevska, A., Skočaj, M., Modic, Š., Razinger, J., Sepčić, K. (2020). Aegerolysins from the fungal genus Pleurotus Bioinsecticidal proteins with multiple potential applications. Journal of Invertebrate Pathology, 107474. https://doi. org/10.1016/j.jip.2020.107474

Paul, S., Das, S. (2020). Natural insecticidal proteins, the promising bio-control compounds for future crop protection. The Nucleus. https://doi.org/10.1007/s13237-020-00316-1

Peumans, W. J., Van Damme, E. J. (1995). Lectins as plant de- fense proteins. Plant Physiology, 109(2), 347-352. https:// doi.org/10.1104/pp.109.2.347

Pohleven, J., Brzin, J., Vrabec, L., Leonardi, A., Čokl, A., Štrukelj, B., Kos, J., Sabotič, J. (2011). Basidiomycete Clitocybe nebularis is rich in lectins with insecticidal activities. Applied Microbiology and Biotechnology, 91(4), 1141-1148. https:// doi.org/10.1007/s00253-011-3236-0

Rane, A. S., Venkatesh, V., Joshi, R. S., Giri, A. P. (2020). Molecular investigation of Coleopteran specific a-amylase inhibitors from Amaranthaceae members. International Journal of Biological Macromolecules, 163, 1444-1450. https://doi.org/10.1016/j.ijbiomac.2020.07.219

Reed, G. L., Jensen, A. S., Riebe, J., Head, G., Duan, J. J. (2001). Transgenic Bt potato and conventional insecticides for Colorado potato beetle management: comparative efficacy and non-target impacts. Entomologia Experimentalis et Applicata, 100(1), 89-100. https://doi.org/10.1046/j.15707458.2001.00851.x

Ryan, C. A. (1990). Protease inhibitors in plants: Genes for improving defenses against insects and pathogens. Annual Review of Phytopathology, 28(1), 425-449. https://doi. org/10.1146/annurev.py.28.090190.002233

Sabotič, J., Kos, J. (2012). Microbial and fungal protease inhibitors - Current and potential applications. Applied Microbiology and Biotechnology, 93(4), 1351-1375). https:// doi.org/10.1007/s00253-011-3834-X

Sabotič, J., Ohm, R. A., Künzler, M. (2016). Entomotoxic and nematotoxic lectins and protease inhibitors from fungal fruiting bodies. Applied Microbiology and Biotechnology, 100(1), 91-111). https://doi.org/10.1007/s00253-0157075-2

Schlüter, U., Benchabane, M., Munger, A., Kiggundu, A., Vorster, J., Goulet, M. C., Cloutier, C., Michaud, D. (2010). Recombinant protease inhibitors for herbivore pest control: A multitrophic perspective. Journal of Experimental Bota$n y$, 61(15), 4169-4183. https://doi.org/10.1093/jxb/erq166

Singh, S., Singh, A., Kumar, S., Mittal, P., Singh, I. K. (2020). Protease inhibitors: recent advancement in its usage as a potential biocontrol agent for insect pest management. Insect Science, 27(2), 186-201. https://doi.org/10.1111/17447917.12641

Šmid, I., Gruden, K., Buh Gašparič, M., Koruza, K., Petek, M., Pohleven, J., Brzin, J., Kos, J., Žel, J., Sabotič, J. (2013). Inhibition of the growth of Colorado potato beetle larvae by macrocypins, protease inhibitors from the parasol mushroom. Journal of Agricultural and Food Chemistry, 61(51), 12499-12509. https://doi.org/10.1021/jf403615f

Šmid, I., Rotter, A., Gruden, K., Brzin, J., Buh Gašparič, M., Kos, J., Žel, J., Sabotič, J. (2015). Clitocypin, a fungal cysteine protease inhibitor, exerts its insecticidal effect on Colorado potato beetle larvae by inhibiting their digestive cysteine proteases. Pesticide Biochemistry and Physiology, 122, 59-66. https://doi.org/10.1016/j.pestbp.2014.12.022

Srp, J., Nussbaumerová, M., Horn, M., Mareš, M. (2016). Digestive proteolysis in the Colorado potato beetle, Leptinotarsa decemlineata: Activity-based profiling and imaging of a multipeptidase network. Insect Biochemistry and Molecular Biology, 78, 1-11. https://doi.org/10.1016/j. ibmb.2016.08.004 
Trdan, S. (2013). Insecticides - Development of safer and more effective technologies. V Insecticides - Development of Safer and More Effective Technologies. InTech. https://doi. org $/ 10.5772 / 3356$

Trdan, S. (2016). Insecticides Resistance. V Insecticides Resistance. InTech. https://doi.org/10.5772/60478

Tripathi, A. K., Mishra, S. (2016). Biotechnological Approaches. V Ecofriendly Pest Management for Food Security (str. 685-701). Elsevier Inc. https://doi.org/10.1016/B978-012-803265-7.00022-1

USEPA. (2010). BIOPESTICIDES REGISTRATION ACTION DOCUMENT. Bacillus thuringiensis Cry3Bb1 Protein and the Genetic Material Necessary for Its Production in MON 863 and MON 88017 Corns. http://www.epa.gov/pesticides/biopesticides/pips/cry3bb1-brad.pdf

Vandenborre, G., Smagghe, G., Van Damme, E. J. M. (2011). Plant lectins as defense proteins against phytophagous insects. Phytochemistry, 72(13), 1538-1550). https://doi. org/10.1016/j.phytochem.2011.02.024

Varrot, A., Basheer, S. M., Imberty, A. (2013). Fungal lectins: Structure, function and potential applications. Current Opinion in Structural Biology, 23(5), 678-685). https://doi. org/10.1016/j.sbi.2013.07.007

Visal, S., Taylor, M. A. J., Michaud, D. (1998). The proregion of papaya proteinase IV inhibits Colorado potato beetle digestive cysteine proteinases. FEBS Letters, 434(3), 401-405. https://doi.org/10.1016/S0014-5793(98)01018-7

Walski, T., Van Damme, E. J. M., Smagghe, G. (2014). Penetration through the peritrophic matrix is a key to lectin toxicity against Tribolium castaneum. Journal of In- sect Physiology, 70, 94-101. https://doi.org/10.1016/j. jinsphys.2014.09.004

Wang, K., Shu, C., Zhang, J. (2019). Effective bacterial insecticidal proteins against coleopteran pests: A review. Archives of Insect Biochemistry and Physiology, 102(3), e21558. https://doi.org/https://doi.org/10.1002/arch.21558

Wang, M., Triguéros, V., Paquereau, L., Chavant, L., Fournier, D. (2002). Proteins as active compounds involved in insecticidal activity of mushroom fruitbodies. Journal of economic entomology, 95(3), 603-607. https://doi. org/10.1603/0022-0493-95.3.603

Wang, W., Hause, B., Peumans, W. J., Smagghe, G., Mackie, A., Fraser, R., Van Damme, E. J. M. (2003). The Tn antigenspecific lectin from ground ivy is an insecticidal protein with an unusual physiology. Plant Physiology, 132(3), 1322-1334. https://doi.org/10.1104/pp.103.023853

Whalon, M. E., Miller, D. L., Hollingworth, R. M., Grafius, E. J., Miller, J. R. (1993). Selection of a Colorado potato beetle (Coleoptera: Chrysomelidae) strain resistant to Bacillus thuringiensis. Journal of Economic Entomology, 86(2), 226233. https://doi.org/10.1093/jee/86.2.226

Wolfson, J. L., Murdock, L. L. (1987). Suppression of larval Colorado potato beetle growth and development by digestive proteinase inhibitors. Entomologia Experimentalis et Applicata, 44(3), 235-240. https://doi. org/10.1111/j.1570-7458.1987.tb00550.x

Zhu, K., Huesing, J. E., Shade, R. E., Bressan, R. A., Hasegawa, P. M., Murdock, L. L. (1996). An insecticidal N-acetylglucosamine-specific lectin gene from Griffonia simplicifolia (Leguminosae). Plant Physiology, 110(1), 195 LP - 202. https://doi.org/10.1104/pp.110.1.195 